\title{
MEDITATION AS PRACTICAL THEOLOGICAL INSTRUMENT IN CONNECTING CHRISTIAN SPIRITUALITY WITH SOCIAL JUSTICE IN THE SPACE OF SERVICE DELIVERY
}

\author{
Fritz de Wet \\ School for Biblical Counselling and Church Ministry \\ North-West University
}

\begin{abstract}
Should the praxis of meditation necessarily lead to avoidance of the world or could it be seen as an activity that can open a vision and level of engagement that will enable the contemplative person to be connected more faithfully and compassionately with this world? With this question as point of departure the researcher explores the possible function of Christian meditation as a means of interacting faithfully and integrally with the space of service delivery in its local manifestation, as well as in its distinctive fluidity in South-African society. Reflecting on the dynamics of a responsible theological entry into this social space, two perspectives from the Reformation regarding the function of meditation in the Christian life are re-visited: Martin Luther's deployment of the interactive sequence 'oratio, meditatio, tentatio', as well as John Calvin's use of the phrase 'meditatio vitae futurae'. By bearing the implications of these two perspectives in mind, an attempt is made to draw normative theoretical lines for a Word-anchored meditative praxis that can become instrumental in opening up a vision for continuity between the present alienated situations in service delivery and their re-created future; an energizing vision that will enable contemplative people to minister the first fruits of a kind of service that entails much more than we could have imagined.
\end{abstract}

Key Words: Meditation; Spirituality; Reformation; Practical Theology;

Service Delivery; Social Justice

\section{Introduction}

It belongs to the essence of the act of meditation to enter a quiet space - amidst an otherwise turbulent and over-exposed life. Time for contemplative Scripture study and prayer in the presence of the Source of spiritual illumination seems to be hard to find. This problem points to a neglected theological theme that should be explored anew (Tubbs Tisdale, 2010:23). In 2011 a group of researchers from the Appeldoorn Theological University published an anthology of essays titled: "Stil tot God - Opstellen rond een verwaarloost theologisch thema" (Quiet in the presence of God - Essays on a neglected theological theme). In this publication the research group contemplates the problem of human senses being overburdened by a hectic schedule and constant impulses from the electronic media - impulses that demand immediate attention (Den Hertog (ed.), 2011:8).

The function of meditation in religious life (with its typical elements of solitude and tranquillity) can easily be associated with (and limited to) an inward journey or - according 
to the new-Platonist line of thinking - with breaking free from this material world and finding inner calm on a higher spiritual plain. However, the question could be asked: Should the praxis of meditation necessarily lead to avoidance of the world or could it be seen as an activity that can open a vision and a level of engagement that will enable the contemplative person to be connected more faithfully and compassionately with this world? (cf. Baars, 2011:70)

Can we -in exploring this question - arrive at a point where we are enabled to visualize a new theological space, where the spirituality sphere (usually associated with the tranquil [pacifistic], non-materialistic and internalizing activity of the 'inner-life' in new-Platonist thinking) and the socio-political sphere (usually associated with activist, justice-seeking and communally based practices in the material dimension of the 'outer life') (cf. WeaverZercher, 2005:2) are linked integrally?

This article attempts to align a practical-theological theory for the function of meditation with the current socio-political situation of service delivery in the South-African context; especially regarding the distinct space and tension fields in which service delivery is acted out in this particular context. Service delivery can be seen as the raison d'etre of municipalities at the local level of government (Van der Waldt, 2012:375). Citizens of a state experience government more directly at local level, because of the physical nearness of this sphere of government to their daily existence. Interaction between local government and citizens takes place due to service delivered to and utilized by people. Not only locality (locality as nearness and in-the-face presence) but also fluidity (in the destabilizing, risking, uncontrolled but also anticipatory and opportunity-presenting sense of the word) seem to be characteristic of the space in which service delivery is practiced (or neglected), encountered (experienced) and assessed. We find ourselves in a space in which responsibility can be evaded by shifting blame; a space in which a culture of demand can overflow quite rapidly and turn unpredictably into violent protest; we find ourselves in a space in which the church with its call to prophetic witness can feel very uncertain and out of its depth due to its legacy of power abuse for the protection of own interests, and can be hesitant due to reservations about playing an active role on 'secular' terrain. In short, we find ourselves in a space where things don't seem to be neatly arranged and under control.

The researcher intends to make a contribution regarding the possible function of Christian meditation in interacting faithfully and integrally with the space of service delivery; entering this space in its local manifestation as well as in its fluidity, from a responsible theological vantage point.

The practical theological reflection develops along the following lines in this article:

- The concept of service delivery, its dynamics in the South African society and the space that needs to be visualized when encountering this action field theologically are discussed;

- With the eye on defining meditation as a practical theological instrument for entering the space of service delivery, two perspectives from the Reformation are revisited: Martin Luther placed the act of meditating on Holy Scripture right in the middle of this life and its intricacies, with his interactive sequence Oratio, Meditatio, Tentatio; John Calvin used the phrase Meditatio Vitae Futurae as a Christ-focused visualisation of the future life in its hope-generating dynamic for engaging this life integrally - also in its socio-political sphere;

- By bearing the implications of these two perspectives in mind, an attempt is made to draw normative theoretical lines for a Word-anchored meditative praxis that seeks a 
kind of clarity in the troubled waters of the turbulent space of service delivery that none of us can produce by means of our own mental efforts alone; a meditative praxis that will open the eyes and the hearts for the true state of our world and for what is needed to deliver (minister) the firsts fruits of a type of service that entails much more than we could have imagined.

Before we proceed with the reflection, the way in which the author deploys the normative element as well as the public scope of practical theological research in the course of this article, need to be clarified.

One of the key tasks of practical theology concerns activating the vitality of normative elements in directing the fulfilment of human life. The main focus of the research activity as documented in this article - is to develop adequate normative theory in interaction with a description of the space of service delivery in the South African context, an interpretation of the theological vantage point needed to enter this space and strategic indicators for renewal in this space ${ }^{1}$.

In a narrow view on the scope of practical theology the proper role of this discipline is merely to inform pastors and congregations about their various tasks and functions that are not seen in relationship to a wider context. By contrast, a public practical theology takes quite seriously the public's role as an audience of its work, both by addressing issues of the common life - local, national, and global public concerns - and by bringing theology into dialogue with contemporary culture (Osmer \& Scweitzer 2003:216). Practical theological research needs an approach that works with theological as well as anthropological perspectives in the real world situation and explores faith as it is acted out in the interrelationship between God and humans, and humans with each other (Pieterse, 2011:1; Immink 2005). In this article, the author consciously sees the public sphere as a space in which human life can only flourish when it is brought into restored contact with the living God.

\section{A Theological Sense for Entering the Space of Service Delivery}

Problematic Elements in the Space of Service Delivery

Any democratic government has the responsibility of providing basic services to its citizens, and such services should be provided at the highest possible level of responsiveness and efficiency (Johnson, 2004:77; Mpehle, 2012:216). Service delivery is acted out mainly at local level of government. Citizens of a state experience government more directly at local level, because of the physical nearness of this sphere of government to their daily existence. Interaction between local government and citizens takes place due to service delivered to and utilized by people. Citizen's perception regarding the question of whether government serves the common interest is determined by the level on which they experience the quality of services that directly and immediately influence their quality of life; services such as provision of electricity, water, sanitation and garbage removal (Van der Waldt, 2012:375).

In the South African society service delivery is acted out in a hugely problematic action field. The problem that impedes or delays service delivery in South Africa's villages and townships is - to the mind of Manala (2010:520) - caused by lack of commitment to

See Osmer (2008:4-12) for a discussion on the interrelationship between the descriptive, interpretative, normative and strategic tasks of practical theology. 
serving others and the apparently exaggerated desire for self-aggrandisement. According to Manala (2010:520) this phenomenon can — be traced to the legacy of apartheid; in the sense that apartheid's reign could have had the effect of perverting morality and dehumanizing the majority of South African citizens, and in the process damaging the moral fibre and integrity of the entire nation. The values of serviceability and self-giving seem to have been eroded by the apartheid opium.

In the current democratic dispensation South African citizens are not perceived as mere consumers or recipients of services, but as an integral part of governance, and therefore need to be involved in decision-making processes regarding services that affect them. The revolution on public service has, to a great extent, been mobilised by the workers' unions which emphasise active participation of citizens in the decisions taken by government, as those decisions have direct bearing on their day-to-day lifestyle (Mpehle, 2012:218). Service delivery protests have become a way of life in South Africa. The protests are becoming increasingly violent, resulting in damage to property and even loss of life. The South-African Institute for Race Relations has noted more than 6000 protest of a general nature since 2002 (as noted by Van der Waldt [2012:375]). This confirms that local government finds itself in a state of crisis. Communities are becoming exceedingly intolerant towards empty election promises, non-response, immoral council members and corruption (Van der Waldt (2012:375).

This brief overview regarding the state of service delivery in the current South African democratic dispensation clearly indicates that the praxis of service delivery (including the action field that surrounds it) is acted out in a fluid, tension-filled space. This space seems fluid enough for playing political power games, in which the blame can be shifted onto others without having to be confronted with the reality of the own inadequacy; in which superficial care for people and empty promises can supposedly be reckoned to be effective enough in masking selfish interests; in which the maximum benefit can be expected from government by means of entitlement whilst at the same time getting away with taking the minimum responsibility on own shoulders. Due to its volatility this is a dangerous, tensionfilled space that can explode at any moment in the faces of those that fail to proof faithful engagement with the matters at hand.

\section{Challenges Faced upon Entering the Space of Service Delivery from a Theological Vantage Point}

When the practical theologian (with the responsibility of introducing the theological dimension entrusted to him/ her) verges on the point of entering this space, matters seem to be further complicated. It is quickly realised that Christians - upon entering into this space - find themselves in a very uncomfortable and disorientating position due to factors such as the way in which the authority of Scripture was abused in the past in order to vindicate a damaging system like apartheid. Others may feel that service delivery takes place on the 'secular' terrain of politics and that the church or the Christian community should not involve itself in activities that can potentially reduce the implications of the Gospel to the social level here and now. Campbell and Cilliers (2012:41) use the word 'liminality' to describe the ambiguous phase between two situations or statuses. The liminal state of displacement breathes a sense of dislocation and disorientation; it exudes a sense of being in no-one's land, of being in a space where the landscape appears completely different from that to which one is accustomed; of being in a space where there is no discernable road map, and the navigator is jolted out of normality. 
Can practical-theological markers be found for faithfully entering this social space, without compromising the character of the Gospel in the process or manipulating the situation from a self-imposed position of superiority? Baker and Reader (2009:5) - writing from their experience with blurred encounters of faith, politics and community in the UK context - propose a thesis for a theology and ecclesiology that ought to be engaging in Third space ${ }^{2}$ /hybrid theory as a way of connecting with the rapidly changing, diverse and pluralizing context of the early 21st century. Baker (2007:132) observes that communities in the early 21 st century democratic society of the United Kingdom are operating in spaces between the local and the global, between the explicit and the implicit and between the solid and the liquid. In the contemporary UK society the political landscape is developing towards a counter-hegemonic space of partnership or coalition, where a number of different partners (including the church), each with their own worldviews and methods of working, come together to forge an alternative space where the rights of all are respected and heard.

Baker and Reader (2009:221) coin the phrase 'serendipitous encounter' as part of the dynamic involved in mapping the new theological space that opens up in the Christian pilgrim's passing through liminal spaces in this world. The noun 'serendipity' materialized along the way as a means of describing sudden, unpredictable, but potentially creative encounters that this new world throws up. There is not always time for the church to marshal the appropriate checks and balances, to try and find previous case histories and precedents. What is required rather is a potentially risky and open encounter, but one which is rooted in virtues of authenticity and faithfulness, and depends on the judicious use of both unstructured (and unfamiliar) and structured (and familiar) spaces.

The position the church finds itself in is indeed complex and calls for a balance between deeply-rooted responsibility and boundary-shifting action, between form and fragment, as well as between implicit and explicit expressions of the Christian identity. In this tension field Grimwood and Winter (2009:114) point to the need for clarity and confidence about what we defend. The opportunity presented to the church in a changing landscape of contradictory encounters is based on the fact that God's kingdom offers genuine deep change, not of facades and false aspirations, but of lasting hope and faithfulness which is foundational to the expression of Christ present in history and future. For Jones (2009:125) the blurred encounter in 'Third space' is not only uncomfortable, but even potentially irredeemable. He urges practical theology and the church to engage more critically with social and political deficits of the current situation by returning to clear principles and values.

\section{Aligning the Theological Vantage Point with the Dynamics of the Current South African Democratic Dispensation}

Focusing on the dynamics of the current South African democratic dispensation, Dreyer (2007:47) reminds us that from the four different models for structuring the relation between religion and state, namely theocratic, repressionist, separationist and co-operative, the choice - in the case of the South African constitution - was made for the co-operative model. This model tends to open a space for freedom against discrimination and coercion.

\footnotetext{
'Third space' refers to lived or existential space, which indicates the immediate, real surroundings in which people find themselves every day (cf. Berquist, 2008:41). 'Third space' is distinguished from 'First space', which can be chartered and indicated geographically and 'Second space', which indicates imagined space (concepts, ideas on how space is or should be).
} 
It is aimed at cultivating mutual recognition and tolerance in accordance with constitutional values, but does not necessarily open up avenues for critical engagement. Dreyer (2007:56) makes a case for the concept of critical engagement. He points to the importance of postconventional religious identity (a concept he learned from Osmer and Schweitzer, 2003) as an appropriate expression of identity in the liminal, blurred, neutral spaces we encounter in the democratic context of interaction between people representing religious matters on the one hand, and state matters on the other hand. Post-conventional identities are identities that remain firmly grounded in the beliefs and practices of a particular religious tradition but are appropriately critical to this tradition, in ways that enable openness to perspectives other than the own. Post-conventional identity is not viewed along the lines of an empty, autonomous self. It should rather be viewed in terms of a narratively-dependent, culturallyrich self that critically appropriates the potential of a particular community or tradition, to engage persons and communities holding perspectives other than the own.

Dreyer (2007:48) works with a public practical theological perspective that challenges public spheres (for example the sphere of education) to recognize and make room for religious identities by providing opportunities for the confrontation between carefully weighed religious convictions. In the process we have to accept the challenge of the formation of religious identities that do not only hold fast to convictions, but are also open to criticism.

\section{Electing to Enter the Space of Service Delivery from a Spirituality of Anticipation}

To my mind, entering the fluid space of service delivery in the current South African democratic dispensation should be undertaken from a critical theological position in which the element of authority of the Christian witness (with its anchors in solid principles, but also with its distinct caring openness to this world) is not based on the own sense to control and dominate (fuelled by factors such as fear and resistance to change). This element should rather be anchored in the pneumatological presence of the Word to which all authority has been given, and whose kingdom is not only breaking through in this world, but will bring all things to consummation (i.e. make all things in heaven and on earth new). In attempting to visualise the impact of this pneumatological position, the space of the kingdom of God should - as an act of faith - be shifted over and brought into living contact with the social space of service delivery, and in the process break the shackles of a dualist frame of mind. Cilliers' (2008:3) concept of 'Fourth space' provides a valuable framework for defining this visualized space. 'Fourth space' is an anticipated space, in the sense of an anticipatory prolepsis of transcendent realities. This anticipation functions in such a manner that the imagined space is not merely viewed from a distance, but that the viewer is seen as someone that already partakes in the object of prolepsis. The transcendent reality enters the viewer's immanent reality, but never to the degree that the transcendent reality can be grabbed and controlled; rather the viewer takes hold of it through faith. To understand (and enter) this form of space one needs a distinctive form of spirituality, and therefore 'Fourth space' could also be called a spiritual space, calling for a spirituality of anticipation. In engaging with the challenging uneasiness and awkwardness of entering 'Third space', the perceiver who looks through the eyes of faith, can witness how 'Fourth space' shifts over 'Third space', providing the promise of hope and peace in a desperate situation.

The next section explores the act of Christian meditation, as a potentially important tool in ministering the impact of the presence of 'Fourth space' in the social space of service delivery and the volatile tension field it finds itself in, by revisiting two profound figures of 
the $16^{\text {th }}$ century Reformation, Martin Luther and John Calvin. This re-visitation functions as an attempt to find normative anchors for entering the space of service delivery with a spirituality of anticipation.

\section{Reformation Roots for a New Perspective on the Functioning of Christian Meditation}

Exploring the Biblical concept of meditation shows that this activity is closely associated with contemplating the Torah of God (Ps 1:2). In the old church meditation was closely associated with the term ruminare. This association probably originated from an allegorical interpretation of texts such as Deuteronomy 14:6, where animals that ruminate are distinguished from the unclean animals. Like a ruminating animal the reader of Scripture should taste, chew and "ruminate on" its contents in order to obtain insight and refreshment from its riches (Baars, 2011:71). Two exponents of Reformation thinking, that link the act of Christian meditation with the faith life flowing from constant interaction with the Word of God, are now considered, namely Martin Luther's praxis of spirituality as it is expressed in the sequence: oratio, meditatio and tentatio on the one hand and John Calvin's concept of meditatio vitae futurae on the other hand. These two exponents are considered as material that can potentially assist the researcher in formulating normative theory for a Word-based spirituality of anticipation. The purpose of this normative theory is to provide an adequate theological vantage point for responsible interaction with the space of service delivery.

\section{Martin Luther's Interactive Sequence: Oratio, Meditatio and Tentatio}

Martin Luther distinguished his own praxis of spirituality from the tradition of spiritual formation he experienced as a monk. The goal of the traditional method was to experience ecstasy, rapture and illumination through union with the glorified Jesus in a contemplative state of mind. To reach this goal, a monk ascended in three stages, as on a ladder, from earth to heaven and from the humanity of Jesus to his divinity. The ascent began with reading out aloud to himself a passage from the Scriptures to quicken the affections, it proceeded to heartfelt prayer, and culminated in the meditation on heavenly things, as one waited for the experience of contemplation, the bestowal of spiritual illumination (Nicol, 1984:80).

In contrast to the manipulative method of the monks, Luther developed an evangelical pattern of spirituality as reception, rather than self-promotion. This spirituality involved three things: prayer (oratio), meditation (meditatio), and temptation (tentatio). (This trio was developed by Luther leading from his interpretation of Psalm 119, a psalm in which according to Luther - the life of prayer and spiritual attack that needs to be dealt with in this life are closely associated with contemplating Scripture. All three these actions revolved around on-going, faithful attention to God's Word. The three terms describe the life of faith as a cycle that begins with prayer for the gift of the Holy Spirit, concentrates on the reception of the Holy Spirit through meditation on God's Word and results in spiritual attack (Anfecthung). This in turn leads a person back to further prayer and intensified meditation. Luther did not envisage the spiritual life in active terms as a process of selfdevelopment but in passive terms as a process of reception from the Triune God (Kleinig, 2002:258; Baars, 2011:77). 
With this conceptualization regarding the meaning of meditation, Luther distinguishes himself from the medieval mystical form of meditation that finds its purpose in the otherworldly observation of the living God. Luther associates meditation with an action that places it in the midst of this world and its constant struggle with sin and the powers of darkness (Baars, 2011:77).

Luther's meditative sequence is not so much a matter of three cumulative rules or three steps following the one after the other; they rather represent three moments of interplay within a single process. In this sense a theologian driven by Anfechtung, delves into Holy Scripture prayerfully, is himself or herself interpreted by it in order that he or she may then interpret to others who are in the midst of Anfechtung, so that they - likewise in prayer may delve into Scripture and be interpreted by it. The concept of theology indicated by this sequence is constitutively 'monastic' although at the same time it is open to 'scholastic' elements and, in fact, needs to employ these 'scholastic' elements in a regulative function (Bayer, 2011:383).

In contrast to the monastic tradition, which held that the proper practice of meditation led to experience of the glorified union with Christ, Luther taught that the receptive study of the Scriptures in prayer and meditation led to experience of God's Word; the experience of its efficiency, its creativity and its productivity (Kleinig, 2002:263). Strangely the power of God's Word, the power of the Spirit at work through the Word, is experienced most clearly in temptation. Anfechtung is the touchstone that teaches you not only to know and understand, but also to experience how powerful and comforting God's Word is - wisdom above all wisdom (Toon, 1991:179).

Before considering the implications of Luther's Word-anchored meditative sequence for a spirituality of anticipation, John Calvin's concept of meditatio vitae futurae, as another example of a Word-based meditative approach from Reformation thinking, is discussed briefly.

\section{John Calvin's Concept of Meditatio Vitae Futurae}

Calvin's conceptualization regarding the contemplative act of meditatio vitae futurae is embedded in his theology of the kingdom of God (cf. Van Wyk, 2001:192). In commenting on the second petition of the Lord's Prayer, God's kingdom is defined as the sphere where people have submitted themselves to his righteousness by striving for the heavenly life through self-denial (abnegatio nostri) and contempt for the world and their life on earth. The kingdom consists of two aspects, namely that God is to change the evil desires of the flesh through his Spirit, and that God is to reform our senses so that we can obey his sovereignty. In praying the second petition the supplicant desires to be cleansed from all elements of corruption that disturb the peaceable state of the Kingdom of God and pollute its cleanness. The restlessness of the supplicant stems from an act of God that - through hardship - reminds us that we cannot find our source of true rest and peace in this world (Inst. 3.20.42; cf. 3.9.1). The negative side of this sanctification comprises aversion against sin and liberation from earthy concerns that pulls the mind down. The positive side of this frame of mind comprises renewal of life sub specie aeternitatis that finds its purpose in glorifying God and ministering his love to fellow human beings (Baars, 2004:235). This contrast between the earthly life and the heavenly life as it becomes evident in Calvin's conceptualisation can initially make us ask: Up till what extent was he influenced by Platonic dualism? Has the Platonic ontology not permeated his perception too much and 
does he not overly contrast as an 'ideal heavenly' kingdom to a 'despised earthly' kingdom? (Van Wyk, 2001:193; cf. Baars, 2004:226)

Anderson (2003:22,30), however, reasons that Calvin's eschatological conceptualization and its vision for a perfected future (expressed in the contemplative act of meditatio vitae futurae as it is elaborately described in the 1559 edition of the Institutes (3.9)) does not engender indifference to the present world and its social and ecological distress; instead it should be seen as an act that sparks commitment. It is not life in the abstract as a spiritual ideal that we are to contemplate but our own particular life in its promised wholeness. Rather than carrying us away from the present, the contemplative act of meditatio vitae futurae snaps our attention back to the contrast between our present state and what we are to be. The comparison and contrast with our future community in Christ act as a clear prophetic judgment on much in our present lifestyle and action. This judgment remains from first to last a re-creation process. It is basically restorative, rather than punitive or threatening. As a promise, it evokes joy in place of guilt and a longing for the fulfilment of this future life. Anderson (2003:32) interprets Calvin's thinking on the relationship between current and future life as follows:

"Our future life with its promise, joy and freedom actually becomes our present norm - a norm that calls us to be ourselves, in these enduring future terms and not waste our energy trying to secure what is already ours.

"One can say that for Calvin, the person who stands in the meditatio vitae futurae, is already - in a certain sense - living the future life and experiencing its impact, here in this world."

The meditative praxis is thus rather concerned with the frame of mind of the believer in this life and then particularly with the impact of hope as inspiring factor in its focus on the glorified Christ. This hopeful and joyous frame of mind stamps the whole life of the Christian in this world and forms an important incentive towards sanctification of life (Baars, 2011:79).

It should be noted that in Calvin's eschatological thinking the humanity of God's future for us remains thoroughly Christomorphic and is not something to be speculated or fantasized about. The new life of the Christian is essentially a life of pneumatological union with Christ. This is an important aspect to bear in mind when imagining the shape of the new life and the form it takes on in the course of the contemplative act. The future reference has as its only available analogy and norm the Church's memory of Christ, in the past (Anderson, 2003:31). In this sense Calvin's meditative action is Word-based, as it is anchored in the Word that became flesh and lived among us and revealed to us (as it was recorded in Scripture) the pattern and life that is well pleasing to God and is wholly concerned with the glory of his Name. The act of remembering Christ's earthly life is, however, not limited to what He has done in the past. It is aimed at contemplating the fullness of the life of the One who humbled himself by becoming obedient to the point of death, and was highly exalted by the Father to sit at his right hand. For Calvin the act of meditation means that the heart of the Christian - in faith and hope - is lifted to be with the glorified Christ at the right hand of the Father (sursum corda) (as Baars [2004:235] reminds us in his discussion of Calvin's commentary on Colossians 3:1).

Another important aspect to take into consideration regarding the scope of the meditatio futurae vitae is that the contemplating individual should not be seen to be concerned only with his or her own personal relationship with the living Christ. Anderson (2003:33) interprets the implications of the scope of Calvin's meditatio vitae futurae as follows: 
Whatever is said about living proleptically into a future life will distort Christian existence if it is seen only through the optic of typically American individualism. For Calvin our 'in-Christ' status is to be grasped not only as personal and corporeal, but also as corporate reality. To be ourselves, human, in Christ, we must include as essential to our own being, all those other persons whom God unreservedly loves. They are regarded as integral to the completion of our very personhood. Our inalienable, corporate personhood, 'the Body of Christ' is to be envisioned as our teleological promise and challenge.

\section{Theoretical Considerations for a Word-anchored Meditative Praxis Deployed as Practical-theological Instrument in the Space of Service Delivery}

The Word-anchored perspectives of Luther and Calvin on Christian meditation are now utilized in an attempt to develop normative theory for a spirituality of anticipation. This spirituality is visualized as one in which a Word-anchored meditative praxis plays a key role in faithfully engaging with the local and fluid space of service delivery as it manifests in South African context. This section starts with the task of defining the role of meditative praxis in a reformational approach, before proceeding to consider the role of the meditative praxis as a practical theological instrument for faithfully negotiating the problem field in the space of service delivery.

Theoretical considerations flowing from Reformation thinking - as it became evident in the preceding discussion of Luther's and Calvin's visions for meditative praxis - will always keep the Word-anchored nature of the act of Christian meditation in mind. The Word of God (as it is revealed in Scripture and makes all things new through the pneumatological presence of the crucified and glorified Christ) will be seen as the ultimate source of wisdom and power for the contemplative mind that seeks God and desires to live for his glory alone. Reformation thinking will not see the act of meditation as a means of self-promotion, but will be inclined to take its point of departure in the evangelical notion that clarity, peace and newness of life are always a graceful gift of God received by the empty hands of faith. In this line of thinking, the meditative person can never ascend into the heavenly planes by own effort, but is lifted up by the powerful work of the Spirit towards faith communion with the glorified Christ and is set by the guidance of the same Spirit to live out his/ her calling in this world.

Consciously working with these meta-theoretical assumptions of the reformed spirituality as point of departure, the following defining theoretical lines can be drawn for the flow of Christian meditation in its practical-theological action field:

- The act of meditation is directed at bringing the contemplative mind into living communion with the Word of God. It consists of prayerfully contemplating the revealed Word of God (as it is documented in Scripture) in organic unity with being drawn towards communion with the living Word that became flesh, the Glorified Christ, in his place of glory and authority at the right hand of God in heaven. It is through the graceful pneumatological act of the Spirit of the Word that the mind is focused on the glorified Christ and the heart is lifted up in living communion with Him.

- Christian meditation moves in the bi-polar tension field of painfully being opened up to the factors that distort, impede and corrupt God-given life in our hearts and in our world (Anfechtung) on the one hand, and the joyful hope of anticipating the fullness of God-consummating life in Christ that is already breaking through into our reality 
like the first rays of a new dawn, on the other hand. The journey embarked on in the meditative praxis travels the full path through theologiae crucis to theologiae gloria.

- Although the act of meditation contains an element of entering into a quiet space where clarity and peace are sought in the face of turbulence, it should not be concluded in an isolating and individualising manner. The clarity and peace found in the presence of God as He reveals Himself and makes us partake in communion with him through his Word, always leads to energized engagement with this world. Dietrich Bonhoeffer qualified the essence of being Christian today as limited to two basic things: prayer and righteous action among humanity. All Christian thinking, speaking, and organizing must be born anew out of this prayer and action. This qualification by Bonhoeffer demonstrates that the goal of Christian maturity is not a spiritual seesaw between prayer and action. Rather the goal is for the spaces between prayer and action to grow narrower until we find a paradoxical union of contemplation and manifestation (Groff, 2005:151).

After drawing normative theoretical lines for defining the act of meditation in reformation context, the role of the meditative praxis as a disclosing and energizing practical theological instrument in the space of service delivery can now be considered. Service delivery in the South African context - as noted earlier - takes place in a local and fluid space; a space that is volatile and contains elements such as tension, turbulence and uncertainty in its action field. To what extent can a spirituality of anticipation, that deploys the praxis of Christian meditation as its primary practical theological instrument, bring elements such as clarity, bold action and hopeful renewal in its wake? In answering this question I would like to propose three movements in the meditative process of entering the space of service delivery, moving from new vision, through boldness that overcomes obstacles, to new action:

\section{- By means of meditation as practical theological instrument, a new vision can} shift into focus through interaction and in living union with the Word of God A pneumatological contemplation of Hebrews 2:5-18 can be taken as an example of how the visionary element of shifting 'Fourth space' over 'Third space' can function in the Word-anchored meditative praxis. Although we do not yet see that all things are made subject to man (as a creature destined to be a royal being) we see Jesus Christ through the eyes of faith crowned with honour and glory because of his suffering and death. The Spirit opens the eyes of faith to see that the current humiliated picture of man subjected to his own desire to make a name for himself without giving others their due (and in the process living under the pathetic misconception that being served [and not serving others] leads to fulfilment of life), is not frozen in the final frame of the human story. In the course of the meditative act another frame can be visualised as shifting over the stark reality of the picture of humiliation seen in 'Third space'. By proleptically imagining the presence of the royal figure of Jesus Christ (glorified, having served the will of his Father until death), the crippled and burdened picture of humiliation is bent open in order that an unburdened and royal human figure can emerge in the final frame of the sequence in living union with Christ. Those being humiliated by the consequences of their own self-indulgent desires and those being humiliated by the lack of service from their leaders alike, can be lifted up to imagine a life in which all can radiate the glory of God's royal destiny for mankind in Christ. 
- Through meditation as practical theological instrument a boldness can be opened up to engage with the full implications of the problem field

Can the meditative praxis release a kind of boldness that will enable the contemplating person to conquer his/her preoccupation with protecting the own comfort zone? Entering a problem field from an untouchable position kept intact by a self-preservative frame of mind, can cause the engagement to deteriorate into abuse of power and can try to gain freedom from anxiety by upholding the status quo with rigid pre-fabricated answers. Cilliers and Campbell (2012:42) refer to a 'closed seriousness' (flowing from the fear that dominates and closes the mind when power and a sense of control are threatened) as a spokesperson of power; it is a kind of seriousness that terrorises, demands and forbids. Over against 'closed seriousness' an open form of seriousness should be considered. Open seriousness is always ready to submit to death and renewal. Cilliers and Campbell (2012:21) reason that the cross is an apocalyptical interruption or invasion of the old age the old myths and conventions and rationalities of the world - by the new. As such, the cross unmasks the powers of the old age for what they are: not the divine regents of life, but the agents of death. And the cross inaugurates the new age or new creation right in the midst of the old. And by interrupting the old age with the new, the cross creates a space where we may be liberated from the powers of death, both to resist their deadly ways and to begin living in the new creation.

By entering the space of service delivery with an open seriousness inaugurated by the cross (as it is revealed in and by the Word), and not flinching from the element of Anfechtung opened up in the process, the contemplative person is emboldened to risk the safe ground of the own unchallenged, privileged position as first priority. A way is opened up for him/ her to be enabled to lose his/her life in service of others with the eye on the glorified One, who gained an immeasurable fullness of life through his self-giving act. The critical engagement with the unacceptability of undelivered service delivery does not have to proceed from the mind-set of a culture of entitlement (demanding the maximum benefit from service delivery without taking any responsibility on the own shoulders to serve others) any longer. The contemplative person can rather be prepared to challenge his/her own mind and the minds of others prophetically, to explore the rich blessings and abundance of life that proceed from and crown a life of true service delivery.

- Through meditation as practical theological instrument the contemplative person can be energized to observe a new kind of action, in which God's love for this world is expressed.

Until we get the internal and external aspects of Christian discipleship (practices of spirituality such as prayer, devotional reading of Scripture and meditation on the one hand and social activism and action in the public realm on the other hand) back together again, neither our spirituality nor our activism will be all it could be (Tubbs Tisdale, 2010:22). Unless Christian meditation results in finding richer and more loving relationships with other human beings or in changing conditions in the world that cause human suffering, the chances are that an individual's prayer activity will fizzle out (Kelsey, 1976:62). The meditative act that - through contemplation of the Word of God - is aimed at observing the newness of life as the loving God wishes us to see it, cannot but culminate in the observance of new action in which this vision for the newness of life is actively expressed as it flows unhindered from a heart opened up by God's grace. Observation (as an act) 
cannot but adhere willingly and gladly to what is observed (seen) in the Word of God through the working of the Spirit (cf. Rudolf Bohren's (1975:138) deployment of the concept of Wahrnehmung with its double meaning of theological aesthetic vision as well as the action that cannot else but proceed from this vision). In other words, the meditative process culminates in a special kind of action that is determined by aesthetic vision.

In the context of the social sphere, the current state of service delivery does not reflect the fullness of life that God intends for humanity. The vision that fills the contemplating mind will lead rather to an active prophetic call for a level of reformation in the sociopolitical sphere, that transcends renewal hampered by closed-ness; a level of reformation that will not merely preserve hidden motives of self-gain and will not merely be aimed at meeting the demands of a passive culture of entitlement. This prophetic call imagines a reality that remains unattainable to conventional, closed human wisdom; it imagines a reality based on excess rather than exchange, and on gift rather than debt (cf. BieseckerMast, 2005:131). It is energized by a vision that humanity can grow into its royal destiny only by faith union with the One who - through his loving actions of service culminating in his death on the cross - opened up a fullness of liberated life in the glorified communion with his Father for all who belong to Him. This prophetic call will be accompanied by a mindset and a communal lifestyle that reflects the liberty of ministering and sharing God's gift of love for the benefit of all and the willingness to be stewards of the precious resources entrusted to us all. Our phenomenal field is entirely different if we see continuity between present alienated situations and their re-created future - new heaven and new earth (cf. Anderson, 2003:40). Communal acts of voluntary service, such as sharing difficult obtainable resources with frail members of the community, like cleaning the local neighbourhood from accumulated litter, can become turning points in a society paralysed by a culture of impeded service delivery. These acts can be observed with such an energizing joy and corruption-disclosing power that they begin to bear dynamic prophetic witness to the abundant life of the new heaven and earth; a life that will be cleansed from all things that polluted and blocked and impeded its holiness. 


\section{BIBLIOGRAPHY}

Anderson, RK 2003. Corporate Selfhood and Meditatio Vitae Futurae: How necessary is eschatology for Christian Ethics? Journal of the Society of Christian Ethics 23(1):21-46.

Baars, A 2004. Meditatio futurae vitae bij Calvijn. Theologia Reformata 47:225-247.

Baars, A 2011. Ruminare verbum. Over meditatiewe omgang met het Woord, in De Hertog, GC (red.), Stil tot God-Opstellen rond een verwaarloosd theologisch thema, 69-92. Appeldoorn: Theologische Universiteit.

Baker, CR 2007. The hybrid church in the city - Third space thinking. Aldershot: Ashgate.

Baker, CR \& Reader, J (eds.) 2009. Entering the new theological space - Blurred encounters of faith, politics and community. Farnham: Ashgate.

Bayer, O 2011. Lutheran Pietism, or Oratio, Meditatio, Tentatio in August Hermann Francke. Lutheran Quarterly 25(2011):383-397.

Berquist, JL 2008. Spaces of Jerusalem, in Berquist, JL and Camp, CV (eds.), Constructions of space II- The biblical city and other imagined spaces, 4-52. New York: T\&T Clark.

Bohren, R 1975. Daß Gott Schön werde-Praktische Theologie als theologische Ästhetik. München: Kaiser.

Calvin, J 1931. Institutie of onderwijzing in de Christelijke Godsdienst (1559) (Uit het Latijn vertaald door A. Sizoo). Delft: Meinema.

Campbell, CL \& Cilliers, JH 2012. Preaching fools - the Gospel as rhetoric of Folly. Waco: Baylor University Press.

Cilliers, J 2008. In die omtrek van die Gees: 'n besinning oor die ruimtelikheid van liturgie. Praktiese Teologie in Suid-Afrika 23(2):1-22.

Den Hertog, GC (red.) 2011. Stil tot God-Opstellen rond een verwaarloosd theologisch thema. Appeldoorn: Theologische Universiteit.

Dreyer, JS 2007. The national policy on religion and education in South Africa: reflections from a public practical theology. Practical Theology in South-Africa 22(2):40-60.

Grimwood, D \& Winter, J 2009. Kent- the garden of dilemma, in Baker, CR, Reader, J (eds.), 101-114. Entering the new theological space-Blurred encounters of faith, politics and community. Farnham: Ashgate.

Groff, KI 2005. Just prayer, acting justly: Contemplation and manifestation, in WeaverZercher, DL, Willimon, WH (eds.), Vital Christianity - spirituality, justice and Christian practice, 141-153. New York: T\&T Clark.

Immink, FG 2005. Faith - a practical-theological construction. Grand Rapids: Eerdmans.

Johnson, WC 2004. Public administration: Partnerships in public service (3rd ed.) Long Grove: Waveland Press.

Jones, P 2009. Weightless Identity in Post-Material Communities, in Baker, CR, Reader, J, (eds.), Entering the new theological space - Blurred encounters of faith, politics and community, 115-126. Farnham: Ashgate.

Kelsey, MT 1976. The other side of silence - a Guide to Christian meditation. New York: Paulist Press. 
Kleinig, JW 2002. Oratio, Meditatio, Tentatio: What makes a Theologian? Concordia Theological Quarterly 66 (3):255-267.

Manala, MJ 2010. 'A Better Life For All': A Reality Or A Pipe-Dream? A Black Theology Intervention in Conditions of Poor Service Delivery in the Democratic South Africa. Scriptura 105(2010):519-531.

Mpehle, Z 2012. Are service delivery protests justifiable in the democratic South Africa? Journal of Public Administration 47(1):213-227.

Nicol, M 1984. Meditation bei Luther. Göttingen: Vandenhoeck \& Ruprecht.

Osmer, RR \& Schweitzer, F 2003. Religious education between modernization and globalization: New perspectives on the United States and Germany. Grand Rapids: Eerdmans.

Osmer, RR 2008. Practical Theology - an Introduction. Grand Rapids: Eerdmans.

Pieterse, HJC 2011. An open coding analytical model of sermons on poverty with Matthew 25:31-46 as sermon text. Acta Theologica 31(1):95-112.

Toon, P 1991. Meditating as a Christian - waiting upon God. London: Collins.

Tubbs Tisdale, L 2010. Prophetic preaching - a pastoral approach. Louisville: Westminster John Knox.

Van der Waldt, G 2012. Samewerkende regering en munisipale dienslewering: Realiteite en uitdagings. Co-operative government and municipal service delivery: Realities and challenges. Tydskrif vir Geesteswetenskappe 52(3):366- 381.

Weaver-Zercher, DL 2005. Introduction, in Weaver-Zercher, DL, Willimon, WH, (eds.), Vital Christianity - Spirituality, Justice and Christian Practice, 1-10. New York: T\&T Clark. 